\title{
Pengaruh Tarif Iklan Terhadap Keputusan Berlangganan pada Siaran Radio Montini Manado
}

\author{
Iranzo Lorenzo Manemba \\ Johny R.E Tampi \\ Danny D.S Mokuan \\ Jurusan Administrasi Program Studi Administrasi Bisnis \\ Fakultas Ilmu Sosial dan Politik Universitas Sam Ratulangi Manado \\ E-mail: lorenzomanemba@gmail.com
}

\begin{abstract}
This study focuses on the influence of advertising rates on customer decisions with the location of research on Radio Montini as one of the audio media by concentrating on promoting advertising rates or prices. The aim is to find out the extent to which Radio Montini Manado broadcast advertising rates affect customer decisions. The method used is a quantitative method with a simple linear regression analysis approach. The results of this study indicate that Radio Montini advertising rates have a positive and significant effect on Radio Manado's Montini FM customer decisions because it is supported by research results in accordance with the results of the validity and reliability test, the significance test, and the SPSS test results. The effect of advertising rates or prices on customer decisions on Radio Montini is not necessarily the only factor that influences customer decisions, but there are also other factors that could not be examined. Based on the results of this study, it is known that advertising rates or prices have a very strong influence on customer decisions at Radio Montini.
\end{abstract}

Keywords: Advertising Rates, Subscription Decisions.

\section{Pendahuluan}

Industri media memiliki peran penting dalam kehidupan sehari-hari. Media sebagai sarana bagi para penyampai pesan untuk menginformasikan pesan baik dalam bentuk produk barang dan jasa. Selain tugas media sebagai penyampai pesan kepada masyarakat, media juga memiliki sisi bisnis yang perlu diperhatikan demi keberlangsungan hidup media tersebut. Iklan atau pariwara merupakan alat promosi terhadap barang, tempat usaha atau ide yang harus dibayar oleh sponsor.
Iklan dapat melalui berbagai media, media cetak dan media elektronik. dan dalam penelitian ini akan mengambil media radio.

Radio dikenal sebagai media yang populis, praktis dan sederhana. Penyampaian pesan yang dilakukan dengan lisan atau suara menciptakan suasana begitu akrab. Ikatan emosional antara radio dengan pendengarnya lebih mudah terbentuk dibandingkan melalui media lainnya karena radio sangat tersegmentasi dan personal. Walaupun bermunculan media yang lebih modern, radio tidak 
pernah ditinggalkan pendengarnya. Sebagai sarana hiburan, promosi dan informasi radio tetap menjadi pilihan walaupun dalam porsi terbatas.

Tarif iklan menjadi pembanding bagi setiap media massa, karena tarif iklan di radio relative lebih murah dari pada tarif iklan di TV dan iklan di media cetak. Tidak hanya tarif murah saja, melainkan iklan di radio juga dikenal karena sangat dekat dengan pendengarnya. Untuk memperkenalkan suatu produk atau jasa yang diiklankan sangatlah mudah dan praktis diketahui oleh khalayak melalui radio. Media radio juga melakukan pengiklanan terhadap barang dan jasa.

Dalam setiap tarif yang sudah ditetapkan oleh pihak pengiklan, pelanggan yang hendak melakukan pengiklanan akan memperkirakan potensi dari iklan tersebut, apakah mereka bisa mendapatkan income dari iklan tersebut atau tidak. Ada juga pelanggan yang melakukan pengiklanan dikarenakan adanya discon yang begitu besar, sehingga tanpa mempertimbangkan potensi dari jangkauan atau sasaran dari perusahaan periklanan tersebut. Untuk memahami perilaku tersebut maka perusahaan, dalam hal ini radio pengiklan akan mencari cara untuk memahami perilaku pelanggan tersebut.

Ada empat faktor yang mempengaruhi pengiklan dalam keputusan pembelian jasa radio sebagai media iklan. Faktor pertama adalah faktor citra yang disusun oleh enam atribut yaitu rating radio, image radio dan segmen radio, prestise, sasaran wilayah produk, dan positioning produk. Faktor kedua adalah faktor produk dan pelayanan yang terdiri dari atribut format acara, penyiar radio, fleksibilitas kontrak dan layanan administrasi. Faktor ketiga yaitu daya tarik radio yang dicerminkan dengan atribut profil pendengar, jumlah pendengar, dan promosi yang dilakukan radio. Serta faktor keempat yaitu faktor pengiklan yang terdiri dari pengetahuan pengiklan dan anggaran dana yang dimiliki pengiklan.

Dari penjelasan diatas maka kita bisa menyimpulkan bahwa untuk menarik pelanggan sebuah perusahaan seperti radio harus mempunyai prestasi yang cukup di kenal oleh masyarakat. Salah satu strategi yang sering digunakan olah sebagian besar perusahaan adalah promosi.

Di kota Manado, ada kurang lebih 20 stasiun radio. Salah satu stasiun radio yang cukup dikenal dalam masyarakat Kota Manado adalah Radio Montini. Radio montini merupakan sebuah media audio yang cukup banyak diminati masyarakat di Kota Manado. Media ini sudah cukup dikenal karena merupakan salah satu media yang sudah lama ada di Kota Manado. Sebagaimana media radio lainnya, dalam 
upaya melebarkan sayapnya di bidang pemasaran, Radio Montini sedang berupaya untuk menarik pelanggan dibidang penyiaran radio. Hal ini mengngat, salah satu sumber pendapatan radio adalah melalui iklan. Oleh karena itu, maka selain menayangkan berita, dan musik, di selasela penyiaran tersebut, Radio Montini melakukan penyiaran iklan, entah itu iklan produk barang atau pun jasa.

Pemilihan stasiun Radio Montini Manado (106 Fm) di karenakan Radio Montini Manado merupakan salah satu stasiun Radio tertua di kota Manado. Dengan frekwensi 106 Fm radio Montini mempunyai jangkauan sangat besar dan luas. Lokasi juga yang strategis untuk di kunjungi oleh narasumber-narasumber yang di undang untuk mengisi acara talk show. dan berbagai keunggulan dari Radio Montini tersebut.

Oleh karena itu, peneliti berminat untuk melakukan penelitian dengan mengambil tempat pada Radio Montini sebagai salah satu media audio dengan berkonsentrasi pada promosi tarif atau harga iklan. Judul yang diangkat adalah: "Pengaruh Tarif Iklan Terhadap Keputusan Berlangganan Pada Siaran Radio Montini Manado"

Berdasarkan uraian latar belakang yang sudah dipaparkan diatas, maka masalah penelitian ini adalah: Apakah tarif iklan siaran Radio Montini Manado berpengaruh terhadap keputusan pelanggan? Masalah ini hendak dibahas dengan maksud atau tujuan untuk mengetahui sejauh mana tarif iklan siaran Radio Montini Manado berpengaruh terhadap keputusan pelanggan.

\section{Landasan Teori}

\section{Konsep Pemasaran}

Teori pemasaran yang amat sederhana selalu menekankan bahwa dalam kegiatan pemasaran harus jelas siapa yang menjual apa, dimana, bagaimana, bilamana, dalam jumlah berapa dan kepada siapa. Adanya strategi yang tepat akan sangat mendukung kegiatan pemasaran secara keseluruhan. Banyak yang menganggap bidang ini identik atau sama dengan bidang penjualan. Sesungguhnya pemasaran memiliki arti yang luas dari pada penjualan. Bidang penjualan merupakan bagian dari bidang pemasaran, sekaligus merupakan bagian terpenting dari bidang pemasaran itu sendiri. Menurut Kotler (1997:8), pemasaran adalah "suatu proses sosial dan manajerial yang didalamnya individu dan kelompok mendapatkan apa yang mereka butuhkan dan inginkan dengan menciptakan, menawarkan dan mempertukarkan produk dengan pihak lain." Sedangkan Menurut Basu Swastha (2002:17) pemasaran adalah sebuah 
falsafah bisnis yang menyatakan bahwa pemuasan kebutuhan konsumen merupakan syarat ekonomi dan sosial bagi kelangsungan hidup perusahaan. Konsep pemasaran didasarkan pada pandangan dari luar ke dalam. Konsep ini diawali dengan mendefinisikan pasar yang jelas berfokus pada kebutuhan pelanggan, memadukan semua sistem kegiatan yang akan memengaruhi pelanggan dan menghasilkan laba melalui pemuasan pelanggan.

Menurut Basu Swastha (2002:42), marketing mix adalah "kombinasi dari empat variabel atas kegiatan yang merupakan inti dari sistem pemasaran perusahaan yaitu produk, struktur harga, kegiatan promosi, dan sistem distribusi". Ada empat komponen pemasaran barang yang meliputi: produk, harga, saluran distribusi, dan promosi.

1. Produk

2. Harga

3. Tempat.

4. Promosi

\section{Bauran Promosi}

Menurut William J Stanton (1996:158), "Bauran Promosi adalah satu aspek yang penting dalam menuju pemasaran dan sering dikatakan sebagai proses lanjut ini disebabkan karena bauran promosi dapat menimbulkan rangkaian kegiatan selanjutnya dari perusahaan”.
Menentukan variabel promotional mix yang paling efektif merupakan tugas yang sulit dalam manajemen pemasaran, manajemen tidak dapat terlepas dari berbagai macam faktor yang mempengaruhinya dalam menentukan kombinasi yang terbaik dari variabel-variabel promotional mix. "Manajemen tidak dapat terlepas dari berbagai macam faktor yang mempengaruhinya dalam menentukan kombinasi yang terbaik dari variabelvariabel promotional mix". (Basu Swastha (2002:240)). Faktor-faktor tersebut antara lain: 1) dana yang tersedia, 2) sifat pasar, 3) jenis produk, dan 4) tahap-tahap dalam siklus kehidupan barang”.

Alat-alat bauran promosi dikelompokkan menjadi 4 bagian yaitu:

a) Periklanan (Advertising)

Menurut Basu Swatha (2002:245) : "Periklanan adalah komunikasi non individu, dengan sejumlah biaya, melalui berbagai media yang dilakukan oleh perusahaan, lembaga non laba, serta individu-individu". Periklanan bersifat menjangkau masyarakat luas (massal), tidak pribadi tapi secara langsung dengan audien (impersonal) dan dapat menyampaikan gagasan secara menyakinkan dan menimbulkan efek yang dramatif (ekspresif).

b) Promosi penjualan (Sales Promotion) 
Promosi penjualan adalah merupakan kegiatan perusahaan untuk menjajakan produk yang dipasarkan sedemikian rupa sehingga konsumen akan mudah melihatnya dan bahkan dengan cara penempatan dan pengaturan tertentu maka produk tersebut akan menarik perhatian konsumen (Gitusudarmo. 2000:238).

Promosi penjualan sangat responsif karena mampu menciptakan respon audiens terhadap perusahaan. Kelemahan promosi penjualan adalah: a. Kurangnya pertimbangan efektifitas biaya. b. Anggaran iklan dan promosi disusun sendiri-sendiri. Dan c. Peraturan-peraturan yang terlalu dianggap sederhana dalam menentukan keputusan seperti perpanjangan anggaran tahun lalu, presentasi dari perkiraan anggaran penjualan.

c) Publikasi (publication)

Publisitas merupakan cara yang biasanya digunakan juga oleh pengusaha untuk membentuk pengaruh secara tak langsung kepada konsumen agar mereka menjadi tahu dan menyenangi produk tersebut di media masa. Definisi menurut H. Indriyo Gitosudarmo M.Com (2000:240) Publisitas adalah "Suatu alat promosi yang mampu membentuk opini masyarakat secara cepat, sehingga disebut sebagai suatu usaha untuk mensosialisasikan atau memasyarakatkan suatu produk". Definisi menurut Basu
Swastha (2002:273) Publisitas adalah "Sejumlah informasi tentang seseorang, barang, atau organisasi yang disebar luaskan ke masyarakat melalui media tanpa dipungut biaya, atau tanpa pengawasan dari sponsor".

\section{d) Penjualan Personal (Personal Selling)}

Promosi bersifat personal sehingga responsif terhadap perilaku audiens. Penjualan personal mampu membina relasi antara perusahaan dengan konsumen. William G. Nickles yang diungkapkan kembali oleh Basu Swastha personal selling didefinisikan sebagai berikut : Personal selling adalah interaksi antar individu, saling bertemu muka yang dirujukan untuk menciptakan, memperbaiki, menguasai atau mempertahankan hubungan pertukaran yang saling menguntungkan dengan pihak lain.(2000:260) Dalam pratiknya personal selling lebih fleksibel dibandingkan dengan sarana promosi lainnya, karena tenaga penjual dapat secara langsung mengetahui keinginan, motif, dan perilaku konsumen, sehingga secara langsung dapat melakukan penyesuaian. Tetapi di lain pihak personal selling membutuhkan biaya yang sangat besar jika penggunaanya sangat luas, di samping sulit memperoleh tenaga penjual yang benar-benar berkualitas. Kegiatan personal selling meliputi: Kontak langsung dapat mempengaruhi secara lebih intensif para konsumennya karena dalam hal ini 
pengusaha dapat mengatahui keinginan atau selera konsumen serta gaya hidup, dengan demikian pengusaha dapat menyesuaikan cara pendekatan atau komunikasi dengan konsumen secara tepat dan sesuai (H. Indriyo Gitosudarmo, 2000:240): a) Door to door; b) Mail Order; c) Telephone Selling; d) Direct Selling; dan face to face, dimana seorang penjual dari sebuah perusahaan langsung menemui konsumen untuk menawarkan produknya.

\section{Iklan Radio}

Iklan radio memiliki karakteristik yang hanya dapat didengarkan melalui audio (suara) saja. Suara tersebut dapat berupa voice, suara atau kata-kata manusia yang teratur seperti musik, perpaduan bunyi-bunyian yang teratur dengan ritme tertentu dan harmonis : sound effect, suarasuara yang tidak beraturan maupun efek suara alam.

Menurut Kotler dan Keller yang dialih bahasakan oleh Benyamin Molan (2007:253) Perencanaan media harus mengetahui kemampuan jenis-jenis media utama untuk menghasilkan jangkauan, frekuensi, dan dampak. Media iklan utama bersama biaya, keunggulan, dan keterbatasannya.

Tabel 2.1 Keunggulan dan Keterbatasan di Media Radio

\begin{tabular}{|l|l|l|}
\hline Media & Kenggulannya & Keterbatasannya \\
\hline Radio & Penggunaan & Hanya penyajian \\
\hline
\end{tabular}

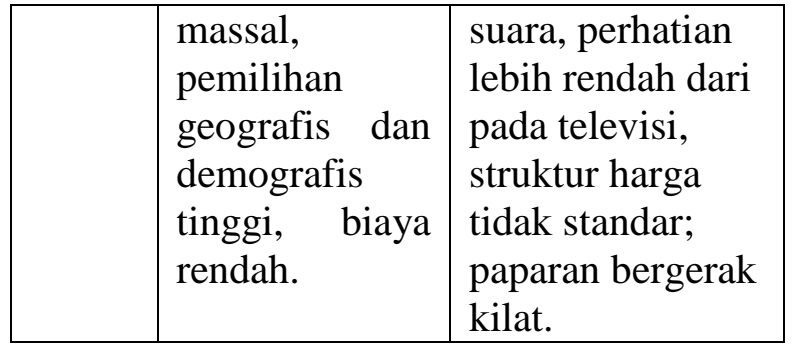

Sumber :Kotler dan Keller yang dialih

bahsakan oleh Benyamin Molan (2007:253)

Dari tabel di atas, hanya bagian saja yang penulis paparkan. Karena dalam tulisan Kotler dan Keller ada berapa media yang di paparkan. Sehubungan penulis hanya memfokuskan pada media siaran radio, maka yang penulis paparkan sesuai keperluan saja. Dengan berdasarkan keunggulan dan keterbatasan media siaran radio di atas, maka kita bisa memahami bahwa iklan yang di siarkan melalui siaran radio, berpotensi menguntungkan perusahaan. Walaupun iklan ini hanya berbentuk suara dan pemaparannya hanya sekilas. Namun, dengan potensi pengguna massal, maka suatu produk atau jasa akan sangat cepat diketahui oleh pelanggan dan calon pelanggan.

\section{Harga Iklan}

Istilah harga dalam bisnis jasa bisa kita temui dengan berbagai sebutan. Universitas/perguruan tinggi menggunakan SPP (tuition), konsultan profesional menggunakan istilah fee, bank memberikan service charge, jalan tol atau jasa angkutan menerapkan tarif, pialang menggunakan 
istilah komisi, apartemen menggunakan sewa, asuransi menggunakan premi, dan lain-lain (Rambat Lupiyoadi, 2001: 86).

Dalam hubungan dengan harga iklan radio, radio menawarkan pendengar sebagai produk unggulannya kepada pengiklan, oleh karena itu harus dibutuhkan penetapan harga iklan. Menetapkan harga iklan adalah hal yang harus diperhatikan oleh perusahaan, sehingga iklan dapat dibeli oleh biro iklan. Penetapan harga dalam pemasaran radio sangat penting mengingat produk yang ditawarkan oleh jasa layanan tersebut bersifat tak berwujud. Harga yang dibebankan terhadap jasa yang ditawarkan menjadikan indikasi kualitas jasa macam apa yang akan konsumen terima. Dalam konteks itu, maka kita bisa memahami bahwa ada konsep atau pengertian dari harga iklan.

Menurut Arfianto, (2010), harga iklan merupakan jumlah uang yang dibebankan untuk produk atau jasa, atau lebih jelasnya adalah jumlah dari semua nilai yang diberikan oleh pelanggan untuk mendapatkan sebuah manfaat dengan memiliki atau menggunakan sebuah produk atau jasa.

\section{Strategi Penyesuaian Harga Iklan}

Menurut Kotler (2000:471), terdapat beberapa strategi penyesuaian harga sebagai berikut:

\section{a) Penetapan harga geografis}

Penetapan harga geografis menuntut pengambilan keputusan perusahaan untuk menetapkan harga produk kepada beberapa konsumen yang berbeda. Dari sudut pandang transaksi antara stasiun radio dan biro iklan, perusahaan yang sedemikian banyak harus berebut biro iklansebagai konsumenyang tentu saja jumlahnya lebih sedikit. Stasiun radio di kota-kota besar dengan membidik segmen dengan SES A1 hingga B2 atau setidaknya C1 menetapkan tarif iklan yang jauh lebih tinggi dibanding stasiun radio di daerah yang membidik konsumen dengan SES C hingga $\mathrm{E}$.

b) Diskon harga dan kelonggaran

Pada umumnya perusahaan akan menyesuaikan daftar harganya dan memberikan diskon dan kelonggaran terhadap pembayaran yang lebih awal, volume pembelian, dan pembelian di luar musim (off-season buying). Perusahaan sebaiknya melakukan hal ini secara berhatihati atau akan mengalami berkurangnya laba jauh dari yang direncanakan.

c) Penetapan harga promosi

Strategi ini biasanya permainan untung-untungan (zero-sum game). Kalaupun berhasil, pesaing akan menjiplak strategi ini dan justru akan kehilangan efektivitas. Tetapi bila gagal, mereka akan membuang-buang uang untuk alat pemasar jangka panjang, seperti membangun 
kualitas produk dan jasa atau memperkuat citra produk melalui periklanan.

d) Penetapan harga diskriminatif

Penetapan harga ini terjadi manakala perusahaan menjual produk atau jasa pada dua harga atau lebih yang justru tidak mencerminkan perbedaan biaya secara proporsional. Di dunia penyiaran, tarif diskriminatif digunakan untuk membedakan waktu yang memungkinkan banyak sedikitnya audiens. Umumnya ada tiga jenis tarif dalam hal ini:

a. Tarif Prime Time: bila dimungkinkan paling banyak pendengar mendengarkan acara pada waktuini.

b. Tarif Reguler: bila ditargetkan setengah dari jumlah pendengar yang diharapkan mendengarkan acara pada waktu tersebut.

c. Tarif Flat Time: bila kurang dari setengah dari jumlah pendengar yang akan mendengarkan acara pada waktu tersebut.

e) Penetapan harga bauran produk

Kita perlu memodifikasi logika penentuan harga manakala produk merupakan bagian dari bauran produk. Dalam hal ini, perusahaan mencari serangkaian harga yang dapat memaksimalkan keuntungan pada total bauran. Penetapan harga seperti ini sulit dilakukan karena berbagai produk memiliki hubungan permintaan dan biaya dan menjadi subjek terhadap berbagai tingkat kompetisi yang berlainan.

\section{Dampak Harga Iklan}

Dampak Harga Iklan

a. Terhadap biro Iklan.

Darmadi Durianto dkk (2003 :17). Memaparkan bahwa secara umum dikenal tiga kriteria yang dapat digunakan untuk mengukur efektivitas periklanan, yaitu: penjualan, pengingatandan persuasi.

1) Penjualan.

Efektivitas ini dapat diketahui melalui riset tentang dampak penjualan. Biasanya sulit dilakukan karena banyaknya faktor-faktor di luar iklan yang berpengaruh secara signifikan terhadap keputusan membeli konsumen. Namun dengan alat analisis yang tepat dimungkinkan untuk melihat peran parsial iklan terhadap penjualan suatu produk.

2) Pengingatan

Dapat diketahui melalui riset tentang dampak komunikasi. Ukuran yang umum dipakai adalah kemampuan mengingat konsumen terhadap iklan atau bagian dari iklan. Konsep pengingatan ini mendapat tentangan karena dianggap tidak mengukur dampak yang paling penting untuk kasus-kasus tertentu. 
3) Persuasi

Seperti halnya efektivitas iklan terkait pengingatan di atas, juga dapat diketahui melalui riset dampak komunikasi. Biasanya yang diukur adalah dampak pemahaman konsumen terhadap suatu iklan, terhadap perubahan kepercayaan konsumen pada ciri atau konsekuensi produk, sikap tersebut merek, merek terhadap membeli merek atau keinginan membeli. Pendekatan lain adalah apakah suatu iklan dapat diinginkan, yaitu menemukan apakah konsumen membentuk pengasosiasian yang tepa tantara merek dengan pribadi konsumen.

b. Terhadap radio

Apabila semua variabel input tersebut di atas dilaksanakan secara professional dengan mempertegas konsep produk dan format stasionnya, didukung terget pendengar yang jelas, sangat dimungkinkan pendapatan iklan dapat diraih tanpa melalui kendala yang berarti. Pendepatan iklan yang tinggi memungkinkan manajemen perusahaan untuk meningkatkan kinerja siarannya melalui peninjauan secara berkala. Dan bukan hal yang mustahil bila stakeholder mendapatkan pengayaan belajar dari sistematika kerja siaran dengan standar internasional seperti $\mathrm{BBC}$, VOA, dan sebagainnya. Pada gilirannya, peningkatan kualitas kinerja siaran ini juga turut mempengaruhi harga iklan untuk mengalami penyesuaian, namun tetap mendapat pengakuan, baik dari pihak biro iklan. Pengakuan juga dating dari pendengar, karena radio dengan harga iklan yang tinggi biasanya memiliki karakteristik tersendiri dalam memelihara hubungan dengan pendengarnya.

\section{Keputusan Berlangganan}

Keputusan pembelian pelanggan merupakan sebuah tindakan yang dilakukan pelanggan untuk membeli atau menggunakan suatu produk atau jasa. Setiap produsen pasti menjalankan berbagai strategi agar pelanggan memutuskan untuk membeli atau menggunakan produk atau jasa yang ditawarkan.

Menurut Kotler (2002), Keputusan pembelian adalah tindakan dari konsumen untuk mau membeli atau tidak terhadap produk. Dari berbagai faktor yang mempengaruhi konsumen dalam melakukan pembelian suatu produk atau jasa, biasanya konsumen selalu mempertimbangkan kualitas, harga dan produk yang sudah dikenal oleh masyarakat.

Sebelum konsumen memutuskan untuk membeli, biasanya konsumen 
melalui beberapa tahap terlebih dahulu, yaitu :

a. pengenalan masalah.

b. pencarian informasi.

c. evaluasi alternatif.

d. keputusan pembelian atau tidak.

e. perilaku pasca pembelian.

Adapun pengertian lain dari Schiffman dan Kanuk (2000 :437) sebagai berikut : "the selection of an option from two or alternative". Dapat diartikan, keputusan pembelian adalah suatu keputusan seseorang dimana dia memilih salah satu dari beberapa alternatif pilihan yang ada.

Berdasarkan defenisi diatas, kita bisa menyimpulkan bahwa keputusan pembelian adalah tindakan yang dilakukan oleh pelanggan untuk melakukan pembelian suatu produk oleh karena itu, pengambilan keputusan pembelian pelanggan merupakan suatu proses pemilihan salah satu dari beberapa alternatif, penyelesaian masalah dengan tindak lanjut yang nyata. Setelah itu pelanggan dapat melakukan evaluasi pilihan dan kemudian dapat menentukan sikap yang akan diambil selanjutnya.

\section{Kerangka Teori dan Kerangka Konsep}

Kerangka pikir penelitian menggambarkan hubungan dari variabel independen, dalam hal ini adalah harga atau tarif iklan $(\mathrm{X})$ terhadap variabel dependen yaitu keputusan berlangganan (Y).

Sedangkan kerangka konsepnya adalah didalam teori pemasaran terdapat empat faktor penting yaitu: 1. Produk, 2. Harga, 3. Promosi, 4. Tempat. Namun sehubungan dengan penelitian ini difokuskan pada tarif iklan maka harga dan promosi yang menjadi hal pokok untuk dijelaskan. Di dalam promosi terdapat bauran promosi begitu juga dengan periklanan, sedangkan periklanan merupakan strategi dari promosi. Sehingga kaitan dari tiga bagian ini sangat erat dalam dunia pemasaran. Didalam periklanan ada faktor penentuan harga atau tarif iklan untuk ditawarkan ke pihak pengiklan sehingga pelanggan bisa mempertimbangkan untuk melakukan pengambilan keputusan.

\section{Metodologi Penelitian}

Penelitian ini dilakukan dengan menggunakan pendekatan kuantitatif, dengan menggnakan metode studi deskriptif, yaitu metode yang diarahkan untuk memecahkan masalah dengan cara memaparkan atau mengambarkan apa adanya hasil penelitian. Tempat penelitian di Radio Montini Kleak Manado, sejak bulan januari sampai dengan Mei 2019. Dalam penelitian ini populasinya adalah semua pelanggan di PT. Modulasi Nada 
Titian Inspirasi Jaya Manado (Montini) yang berjumlah: jumlah pelanggan iklan nasional adalah 16, sedangkan jumlah pelanggan lokal (Sulawesi Utara) berjumlah 32 pelanggan. Berdasakan data tersebut, jumlah keseluruhan populasi berjumlah 48 pelanggan.

Berdasarkan jumlah populasi tersebut, kemudian diambil sampel untuk menjadi sumber penelitian. Sampel dalam penelitian ini adalah sebagian dari jumlah keseluruhan pengiklan di PT. Modulasi Nada Titian Inspirasi Jaya Manado. Teknik pengambilan sampel yang digunakan dalam penelitian ini adalah Simple random sampling (pengambilan sampel acak sederhana). Alasan penulis menggunakan teknik pengambilan sampel ini dikarenakan pengiklan di PT. Modulasi Nada Titian Inspirasi Jaya Manado sering berubah-ubah seiring keperluan pengiklan. Jumlah sampel dalam penelitian ini mengikuti jumlah populasi. Mengingat populasinya hanya sedikit (di bawah 50) maka seluruh populasi adalah sampel. Penentuan jumlah sampel menyesuaikan dengan kemampuan atau daya jangkau karena keterbatasan dana, tenaga dan waktu. Oleh karena itu maka peneliti hanya akan memfokuskan pada populasi yang ada di wilayah Sulawesi Utara saja yang berjumlah 32 sedangkan 16 populasi yang kebanyakan di
Jarakrta dan sekitarnya tidak dijadikan sebagai sampel.

Dalam usaha untuk mengumpulkan data yang dibutuhkan, metode yang digunakan adalah kuesioner (daftar pertanyaan). Data yang dikumpulkan meliputi:

Identitas responden; dan Data mengenai tanggapan responden terhadap variabelvariabel yang mempengaruhi keputusan pembelian. Penelitian in terdiri dari dua variabel, yaitu Variabel Tarif atau Harga Iklan (X) dan Variabel Keputusan Pelanggan (Y). Variabel-variabel tersebut diukur dengan menggunakan skala Likert (skala 1-5) dengan keterangan sebagai berikut: Skor 5 untuk jawaban sangat setuju (SS), Skor 4 untuk jawaban setuju (S), Skor 3 untuk jawaban biasa saja (BS), Skor 2 untuk jawaban tidak setuju (TS), Skor 1 untuk jawaban sangat tidak setuju (STS).

Supaya data yang telah dikumpulkan tersebut dapat bermanfaat maka harus diolah dan dianalisis terlebih dahulu sehingga dapat dijadikan sebagai dasar dalam pengambilan keputusan. Analisis data yang digunakan dalam penelitian ini adalah analisis kuantitatif dengan menggunakan analisis regresi linear sederhana. Analisis regresi linier sederhana digunakan untuk mengetahui ada tidaknya pengaruh harga iklan terhadap keputusan pelanggan di PT. Modulasi Nada Titian 
Inspirasi Jaya Manado. Analisis regresi linear sederhana dilakukan dengan terlebih dahulu melakukan Validitas, Reliabilitas dan Uji t.

\section{Hasil Penelitian}

Uji Validitas, Reliabilitas, dan uji t Hipotesis

Syarat uji validitas adalah: Jika nilai signifikansi ( $\mathrm{P}$ Value) $>0,05$ maka tidak terjadi hubungan yang signifikan. Sedangkan apabila nilai signifikansi (P Value $)<0,05$ maka terjadi hubungan yang signifikan. Setelah memasukan data jawaban responden ke dalam aplikasi SPSS maka hasil penghitungannya adalah sebagaimana terdapat dalam Lampiran 4 Tabel 4.7. Inter-Item Correlation Matrix dan 4.8. Item Total Statistic. Tabel InterItem Correlation Matrix menunjukkan hubungan atau korelasi antar item soal atau pertanyaan. Pada tabel 4.7. di bagian lampiran 4, nilai scale Corrected ItemTotal Correlation menunjukkan nilai validitas butir, yang berarti validitas butirnya $=1,000$. Sedangkan kolom Cronbach's Alpha if Item Deleted adalah nilai reliabilitas butir yang berarti nilai reliabilitas butirnya adalah 0,903 . Untuk menilai apakah validitas butir dan reliabilitas butir adalah valid dan reliabel, maka harus dibandingkan dengan $\mathrm{R}$ tabel pada $\mathrm{df}=\mathrm{n}-2$ dan probabilitas 0,05 . $\mathrm{n}-2=32-2=30$

probabilitas $0,05=5 \%$

Jadi nilai $\mathrm{r}$ tabel pada df $5 \%=0,361$.

Berdasarkan hasil tersebut, maka dapat disimpulkan bahwa semua pertanyaan dinyatakan valid karena nilai $r$ hitung $(0,903)$ dan nilai validitas 1,000 lebih besar dari nilai $r$ tabel 0,361 . Dengan demikian semua pertanyaan dinyatakan valid.

Pada tabel reliability statistics, nilai reliabilitas tes secara keseluruhan terdapat pada kolom Cronbach's Alpha Based on Standarized items. Semakin besar nilainya, maka semakin reliabel. Data tersebut menunjukkan bahwa nilai reliabilitas tes pada kolom Cronbach's Alpha Based on Standarized items adalah 1,000 yang berarti lebih besar dari 0,05. Ketentuannya adalah semakin besar nilainya maka akan semakin reliabel. Oleh karena itu maka penelitian ini dikatakan reliabel.

Analisis data dan pengujian hipotesis dalam penelitian ini menggunakan regresi linier sederhana, untuk menguji sejauh mana pengaruh variabel Harga atau tarif iklan (X) terhadap keputusan berlangganan (Y) iklan di Radio Montini.

Uji hipotesis berfungsi untuk mengetahui apakah koefisien regresi signifikan atau tidak. Sekedar mengingatkan kembali bahwa hipotesis 
yang saya ajukan dalam analisis regresi linear sederhana ini adalah:

Ho ` : Harga iklan radio tidak berpengaruh positif terhadap keputusan

$$
\text { pelanggan. }
$$

$\mathrm{H}_{1}$ : Harga iklan radio mempunyai pengaruh positif terhadap keputusan

$$
\text { pelanggan. }
$$

Untuk memastikan apakah koefisien regresi signifikan atau tidak (dalam arti variabel $\mathrm{X}$ berpengaruh terhadap variabel Y) dilakukan melalui uji hipotesis ini dengan 2 cara, yaitu: membandingkan nilai signifikan (Sig.) dengan probabilitas 0,05 atau dengan cara membandingkan nilai $\mathrm{t}$ hitung dengan $t$ tabel.

Dasar pertimbangan pengambilan keputusan dalam analisis regresi dengan melihat nilai Signifikansi (Sig.) hasil output SPSS adalah: Jika nilai Sig. lebih kecil dari probabilitas 0,05 berarti ada pengaruh harga iklan terhadap keputusan berlangganan; dan jika nilai Sig. lebih besar dari probabilitas 0,05 maka tidak ada pengaruh harga iklan terhadap keputusan berlangganan.

Berdasarkan output spss, diketahui nilai Sig. mines (-) atau lebih kecil dari 0,05, sehingga dapat disimpulkan Ho ditolak dan H1 diterima, yang berarti bahwa ada pengaruh tarif iklan (X) terhadap keputusan berlangganan (Y).
Uji $\mathrm{t}$ dilakukan untuk mengetahui pengaruh masing-masing variabel independen (harga atau tarif iklan) secara parsial terhadap variabel dependen (keputusan berlangganan). Dasar pengambilan keputusan dalam uji t adalah: jika nilai $\mathrm{t}$ hitung lebih besar dari $\mathrm{t}$ tabel maka ada pengaruh antara tarif iklan terhadap keputusan berlangganan. Sebaliknya jika nilai $\mathrm{t}$ hitung lebih kecil dari nilai t tabel maka tidak ada pengaruh antara tarif iklan terhadap keputusan berlangganan.

Berdasarkan output SPSS, diketahui bahwa kolom $\mathrm{B}$, nilai a (constant) $=8,60 \mathrm{E}-$ 0,16 dan nilai $b=1,600$. Nilai-nilai pada kolom Std. Error menyatakan nilai $\mathrm{s}_{\mathrm{a}}=.000$ dan $s_{b}=.000$. Nilai-nilai pada kolom $t$ merupakankan hasil perhitungan rumus uji t hitung untuk intersep $\alpha(\mathrm{t}=-)$ dan koefisien regresi $\beta(\mathrm{t}=-)$. Karena belum ada nilai $\mathrm{t}$ tabel maka kita mencari t tabel dengan menggunakan rumus:

Nilai probabilitas (a) $/ 2=0,05 / 2=0,025$

Derajat kebebasan $(\mathrm{df})=\mathrm{n}-2=32-2=30$

Nilai 0,025 ; df. $30=2,042$

Jadi nilai $\mathrm{t}$ tabel $=2,042$

Berdasarkan output di atas, yang diajukan dalam uji $\mathrm{t}$ ini maka: terdapat pengaruh dan hubungan yang signifikan antara Tarif iklan terhadap keputusan berlangganan pada Radio Montini. 


\section{Pembahasan}

1. Pengaruh antar variabel Tarif atau Harga

Iklan (X) terhadap variabel Keputusan

Berlangganan (Y) berdasarkan Uji

Validitas dan Reliabilitas

Pengaruh variabel $\mathrm{X}$ (harga atau tarif iklan) terhadap vaiabel (Y) keputusan berlangganan diketahui dengan pertamatama melihat hasil uji validitas. Dalam uji validitas, diketahui bahwa semua item pertanyaan adalah valid. Nilai validitas diketahui terdapat pada nilai scale Corrected Item-Total Correlation, yang berarti validitas butirnya $=1,000$. Sedangkan kolom Cronbach's Alpha if Item Deleted adalah nilai reliabilitas butir yang berarti nilai reliabilitas butirnya adalah 0,903. Untuk menilai apakah validitas butir dan reliabilitas butir adalah valid dan reliabel, maka harus dibandingkan dengan $R$ tabel pada $\mathrm{df}=\mathrm{n}-2$ dan probabilitas 0,05 . Nilai $r$ tabel pada df $5 \%=0,361$.

Berdasarkan hasil tersebut, maka dapat disimpulkan bahwa semua pertanyaan dinyatakan valid karena nilai $r$ hitung $(0,903)$ dan nilai validitas $(1,000)$ lebih besar dari nilai $r$ tabel 0,361 . Dengan demikian semua pertanyaan dinyatakan valid.

Pada tabel reliability statistics, nilai reliabilitas tes secara keseluruhan terdapat pada kolom Cronbach's Alpha Based on Standarized items. Semakin besar nilainya, maka semakin reliabel. Data tersebut menunjukkan bahwa nilai reliabilitas tes pada kolom Cronbach's Alpha Based on Standarized items adalah 1,000 yang berarti lebih besar dari 0,05. Ketentuannya adalah semakin besar nilainya maka akan semakin reliabel. Oleh karena itu maka penelitian ini dikatakan reliabel.

Berdasarkan pembahasan di atas, diketahui bahwa nilai uji validitas berada pada kolom Corrected Item-Total Correlation. Dari data tersebut diketahui bahwa seluruh atau masing-masing t hitung lebih besar dari t tabel $(2,042)$ dan bernilai positif. Dengan demikian, butir pertanyaan kuesioner dinyatakan valid. Selanjutnya dalam hasil uji Reliabilitas pada kolom Cronbach's Alpha if item Deleted diketahui bahwa nilai reliabilitas adalah 1, 000 dan bersifat positf dan melebihi nilai standar 0,05. Jadi disimpulkan bahwa data penelitian ini reliabel.

2. Pengaruh antar variabel Tarif atau Harga Iklan (X) terhadap variabel Keputusan Berlangganan (Y) berdasarkan Uji Signifikansi dan Uji t

Pengaruh antar variabel dengan uji signifikansi yang telah dilakukan, diketahui bahwa terdapat hubungan yang signifikan antara tarif atau harga iklan terhadap keputusan berlangganan. Hal ini diketahui 
dengan pertimbangan, dasar pertimbangan pengambilan keputusan dalam analisis regresi adalah dengan melihat nilai Signifikansi (Sig.). Berdasarkan output di atas, diketahui nilai Sig. mines (-) atau lebih kecil dari 0,05 , dalam pengertian lebih kecil dari 5\% sehingga dapat disimpulkan Ho ditolak dan H1 diterima, yang berarti bahwa ada pengaruh tarif iklan (X) terhadap keputusan berlangganan (Y).

Pengaruh antar variabel dengan melihat perbandingan uji $\mathrm{t}$ yang telah dilakukan, diketahui bahwa variabel tarif atau harga iklan $(\mathrm{X})$ berpengaruh terhadap keputusan berlangganan (Y). Dasar pengambilan keputusan dalam uji t adalah: jika nilai $\mathrm{t}$ hitung lebih besar dari $\mathrm{t}$ tabel maka ada pengaruh antara tarif iklan terhadap keputusan berlangganan. Sebaliknya jika nilai $\mathrm{t}$ hitung lebih kecil dari nilai t tabel maka tidak ada pengaruh antara tarif iklan terhadap keputusan berlangganan. Berdasarkan output di atas, yang diajukan dalam uji t maka diketahui bahwa nilai $\mathrm{t}$ hitung lebih besar dari $\mathrm{t}$ tabel yaitu 2,042. Oleh karena itu maka dapat disimpulkan terdapat pengaruh dan hubungan yang signifikan antara Tarif iklan (variabel $\mathrm{X}$ ) terhadap keputusan berlangganan (variabel Y) pada Radio Montini.
3. Pengaruh Harga/Tarif Iklan (X) terhadap Keputusan Berlangganan (Y)

Besarnya pengaruh Variabel Tarif atau Harga Iklan (X) terhadap Variabel Keputusan berlangganan (Y) dalam analisis regresi linear sederhana dapat dilihat dalam nilai R Square atau R2 yang terdapat pada output SPSS bagian Model Summary. Dari output spss, diketahui nilai $\mathrm{R}$ Square sebesar 0,678. Nilai ini mengandung arti bahwa pengaruh tarif atau harga iklan (X) terhadap keputusan berlangganan (Y) adalah sebesar $67,8 \%$ sedangkan $32,2 \%$ keputusan berlangganan (Y) dipengaruhi oleh variabel lain yang tidak diteliti. Artinya dalam penelitian ini, tarif iklan pengaruhnya sangat nampak dan sangat kuat terhadap keputusan berlangganan. Dalam hal faktor lain yang juga turut mempengaruhi keputusan berlangganan, perlu dibuktikan melalui penelitian karena peneliti saat ini hanya memfokuskan pada pengaruh tarif iklan.

Data penelitian sebagaimana dijelaskan di atas sesuai dengan penelitian terdahulu yang dilakukan oleh Ary, Novianto (2005) dengan judul "Analisis faktor yang mempengaruhi tarif iklan pada radio swasta di kota jogja dan solo". Penelitian Ary menunjukan bahwa secara simultan, dari 10 variabel dalam penelitian yang dilakukan, sangat berpengaruh signifikan terhadap tarif iklan radio swasta 
di kota jogja dan solo. Hal yang sama juga berlaku bagi peneliti terdahulu lain, yakni Made Novandri Sn (2010) dengan Judul "Analisis Pengaruh Kualitas Produk, Harga, Dan Iklan Terhadap Keputusan Pembelian Sepeda Motor Yamaha Pada Harpindo Jaya Cabang Ngaliyan”. Hasil penelitian Made menunjukan bahwa secara simultan dan persial, kualitas produk, harga, dan iklan perpengaruh positif dan signifikan terhadap keputusan pembelian sepeda motor Yamaha di Harpindo Jaya cabang Ngaliyan.

Kedua penelitian ini membuktikan bahwa data penelitian yang sudah dilakukan oleh peneliti di atas mengandung kebenaran, dimana promosi tarif iklan akan memberikan dampak positif bagi keputusan berlangganan di Radio Montini. Kedua hasil penelitian terdahulu tersebut memberikan kekuatan empiris bahwa pengaruh tarif iklan dan variabel lain yang tidak diteliti sangat besar terhadap keputusan berlangganan.

Hasil penelitian ini juga didukung dengan teori Kotler (2000) yang menjelaskan bahwa indikator yang mempengaruhi harga iklan Radio adalah: Harga geografis; Diskon harga dan kelonggaran; Harga promosi; Harga diskriminatif; dan Harga bauran produk. Melalui penetapan harga iklan dengan memperhatikan beberapa indikator di atas, maka pihak manajemen radio Montini bisa mengadakan promosi iklan melalui media Radio tersebut dan bisa mendatangkan keuntungan dan pada akhirnya bisa memikat hati pelanggan untuk mengambil keputusan berlangganan di Radio Montini.

Agar supaya pemilihan media Radio sebagai sarana promosi melalui iklan radio bisa mendapat tempat di hati pemirsa, maka hal lain yang menjadi perhatian penting sesuia dengan hasil penelitian adalah faktor-faktor yang mempengaruhi pemilihan media iklan (keputusan berlangganan) sebagaimana dikemukakan oleh Swastha (2002:235), yakni: Tujuan periklanan; sirkulasi media; keperluan berita; waktu dan lokasi dimana keputusan membeli dibuat; biaya advertensi; kerjasama dan bantuan promosi yang ditawarkan oleh media; karakteristik media; dan kebaikan serta kelemahan media. Jika hal ini kurang diperhatikan oleh pihak manajemen Radio Montini maka bisa jadi penelitian ini tidak berfaedah atau kurang berpengaruh antara tarif iklan terhadap keputusan berlangganan sebagaimana hasil penelitian terdahulu yang dilakukan oleh Taufik (2013) dengan julul "Pengaruh Media Iklan Terhadap Pengambilan Keputusan Membeli Pasta Gigi Pepsodent”. Penelitian Taufik menunjukkan bahwa ada pengaruh secara simultan media iklan televisi, radio, majalah, surat kabar, dan 
papan reklame berpengaruh positif dan signifikan terhadap keputusan pembelian pasta gigi Pepsodent sedangkan secara parsial, hanya media iklan televisi, majalah, dan papan reklame berpengaruh signifikan. Media iklan radio dan media iklan surat kabar tidak berpengaruh signifikan terhadap keputusan pembelian pasta gigi Pepsodent.

\section{Simpulan}

Berdasarkan penjelasan di atas, maka dapat ditarik kesimpulan bahwa tarif iklan Radio Montini berpengaruh positif dan signifikan terhadap keputusan pelanggan Radio Montini FM Manado karena didukung dengan hasil penelitian sesuai hasil uji validitas dan reliabilitas, uji signifikansi, dan hasil uji SPSS. Pengaruh tarif atau harga iklan terhadap keputusan pelanggan pada Radio Montini ini tidak serta merta menjadi satu-satunya faktor yang mempengaruhi keputusan pelanggan, namun ada juga faktor lain yang tidak sempat diteliti. Berdasarkan hasil penelitian ini, diketahui bahwa tarif atau harga iklan memiliki pengaruh yang sangat kuat terhadap keputusan pelanggan di Radio Montini.

\section{Referensi}

Arfianto, W. (2010). Analisis FaktorFaktor yang Mempengaruhi Efektivitas Iklan Pada Media
Televisi (Studi Pada Iklan Produk Sepeda Motor Honda). (Doctoral Dissertation.

Diponegoro).

Benyamin Molan (2007)-Alih Bahasa. Philip Kotler and Kevin Lane Keller, Manajemen Pemasaran, Edisi Keduabelas, Jilid 1, Jakarta: PT. Indeks Kelompok Gramedia).

Durianto, Darmadi, dkk. (2003). Inovasi Pasar Dengan Iklan Efektif. (Jakarta: Gramedia Pustaka).

Effendi, Sofyan, (1995). Pelayanan Publik, Pemerataan dan Administrasi Negara Baru, (Jurnal Prisma No. 12, Jakarta: LP3ES).

Ghosali, Imam. (2002). Aplikasi analisis multivariate dengan program SPSS $\left(4^{\text {th }} e d\right)$. (Semarang: Undip).

Gitosudarmo, Indriyo. (2000). Manajemen Pemasaran Edisi Kedua Cetakan. Keenam. (Yogyakarta : BPFE).

Harper W. Boyd, dkk, (2000), Manajemen Pemasaran-Suatu Pendekatan. Strategis Dengan Orientasi Global edisi 2 jilid 2, (Jakarta : Erlangga).

Kotler, Philip (2006). Manajemen Pemasaran, Edisi Pertama. (Indonesia: PT. Indeks Kelompok. Gramedia).

(2002). Manajemen Pemasaran, Edisi Millenium, Jilid 2, (Jakarta: PT Prenhallindo).

(2000). Prinsip-Prinsip Pemasaran Manajemen, (Jakarta: Prenhalindo).

(1997).

Manajemen

Pemasaran Analisis Perencanaan, Implementasi dan Pengendalian 
(terjemahan Jaka Wasana). (Jakarta: Salemba Empat).

Novandri, Made Sn. (2010). Analisis Pengaruh Kualitas Produk, Harga, Dan Iklan Terhadap Keputusan Pembelian Sepeda Motor Yamaha Pada Harpindo Jaya Cabang Ngaliyan". (Jurnal jurusan ekonomi. Semarang).

Novianto, Ary. (2005). Analisis faktor yang mempengaruhi tarif iklan pada radio swasta di kota jogja dan solo. (Jurnal fakultas ekonomi. Surakarta).

Sugiyono, 2011. Metode penelitian kuantitatif, kualitatif dan $R \& D$. (Alfabeta. Bandung).

Sugiyono. 2010. Metode Penelitian Administrasi, (Bandung: Alfabeta)

Schiffman, Leon G. \& Leslie L. Kanuk. (2000). Consumer behavior : Fifth Edition. (New Jersey: Prentice-hall Inc.).

Stanton, William, (1996). Prinsip-prinsip Pemasaran, Jilid Kedua, Edisi Ketujuh, (Jakarta: Erlangga).

Suryanto. (2011). Metodologi dan Aplikasi Penelitian Keperawatan. (Yogyakarta: Nuha Medika).

Swastha, Basu. (2002). Manajemen Pemasaran. Edisi Kedua. Cetakan Kedelapan. (Jakarta: Penerbit Liberty).

Taufik (2013). Pengaruh Media Iklan Terhadap Pengambilan Keputusan Membeli Pasta Gigi Pepsodent.

Umar Husein. (2000), Business an Introduction. (Jakarta: Gramedia Pustaka Utama).
Winarno Surachmad, (1982). Pengantar Penelitian Ilmiah: Dasar, Metode, Teknik, (Bandung: Tarsito) 